Fabrice Darinot*

\title{
Improving detectability of the harvest mouse (Micromys minutus Pallas, 1771) by above ground live-trapping
}

https://doi.org/10.1515/mammalia-2018-0183

Received November 4, 2018; accepted August 27, 2019; previously published online September 19, 2019

Abstract: Harvest mouse detectability represents a real issue for surveys, as usual ground-trap monitoring is known to fail to detect this species, especially in summer. The present study proposes to test ground versus aerial live-trapping efficiency for harvest mouse in summer, with a trapping design using paired ground and aerial traps over a 2-year survey in a reedbed. Over 10,720 trap-nights, the harvest mouse represented $85 \%$ of the 1078 small mammals captured, and it was the only species among five which was more often trapped above ground $(n=702)$ than on the ground $(n=213)$. Capture probability was significantly higher in aerial than in ground traps, with a slightly positive effect of leaf litter and, surprisingly, a negative effect of dense vegetation cover. Following these results, recommendations are made for harvest mouse monitoring.

Keywords: aerial trapping; harvest mouse; population monitoring; reedbed; trapping efficiency.

\section{Introduction}

For small mammal surveys, as for other taxa, applications that rely on occurrence-related metrics cover a wide range of ecological disciplines, including measures of species distribution, habitat selection and modeling, structure and dynamic population studies and wildlife monitoring programs (MacKenzie and Royle 2005). Occurrence detection requires the implementation of techniques that take into account each species' detectability. Indeed, it is known that a species may not be detected in a sampling unit even if it is actually present. Live-trapping is a key technique for monitoring small mammal populations (Flowerdew et al. 2004), but as animals are often not evenly distributed, traps may have different detection

\footnotetext{
*Corresponding author: Fabrice Darinot, EPHE, PSL Research University, UMR 5175 CEFE, CNRS, UM, Univ. P. Valery, SupAgro, IRD, INRA, Biogéographie et Écologie des Vertébrés, 1919, Route de Mende, 34293 Montpellier, France, e-mail: fabrice.darinot@espaces-naturels.fr
}

probability relative to food source, ways of escape or proximity of the surrounding individual's home ranges (Watkins et al. 2010). Moreover, the detection probability of occurrence can be influenced by features of the local habitat or landscape, as well as behavior of individuals (Gu and Swihart 2004). Individual detectability is thus a major issue for small mammal studies, particularly for some species with special behavior like the harvest mouse (Micromys minutus Pallas, 1771) which is known to be difficult to trap in the wild (Flowerdew et al. 2004).

The harvest mouse is a tiny mammal which is widespread in the Palaearctic and Indomalayan regions (Wilson et al. 2016). Although the International Union for Conservation of Nature (IUCN) has assigned the status "least concern" to this species (Aplin et al. 2008), the harvest mouse has the growing attention of scientists and naturalists in some countries like Switzerland and Great Britain where its populations have declined during recent decades (Harris et al. 1995, Perrow and Jowitt 1995, Blant et al. 2012). Unfortunately, it is understudied in the wild compared to other European small mammals, and one of the reasons is that this elusive species appears to be difficult to capture with usual ground trapping methods. The harvest mouse is the smallest rodent in Europe, adults weighing around 7 $\mathrm{g}$, and it is a solitary species with no sexual dimorphism, females sometimes being bigger than males (Rowe and Taylor 1964, Trout 1978). The harvest mouse and the hazel dormouse (Muscardinus avellanarius Linnaeus, 1758) are the only small mammals in Europe able to make aerial nests in tall vegetation. These nests are commonly used to detect the presence of the mice in the wild because they are easy to find, but they do not reflect the actual population size (Riordan et al. 2009). While being able to move on the ground like any rodent, the harvest mouse will also climb up tall vegetation and it is very skillful at jumping from leaf to leaf and grasping thin herbaceous stems.

It is known that trappability of some small mammals may decline during summer months, as for the wood mouse (Apodemus sylvaticus Linnaeus, 1758) (Butet 1994, Butet and Paillat 1997), but it is even more pronounced for the harvest mouse (Sleptsov 1947, Trout 1978). Trout (1978) observed a drastic decrease in population density during three consecutive trapping years, from an average 
of 200 individuals/ha during autumn and winter to almost zero in late spring and summer. He supposed that ground trapping was responsible for that decline, while wondering if there could be a natural fluctuation in population size. On the other hand, trapping above ground was successfully tested for the harvest mouse by some authors (Warner and Batt 1976, Nordvig et al. 2001, Riordan et al. 2009, Vogel and Gander 2015, Kettel et al. 2016). Except for Riordan et al. (2009), these studies tend to show that the harvest mouse trap-success is higher with elevated than ground traps in autumn, winter and spring. Only Vogel and Gander (2015) carried out an experiment in summer months, a crucial period when individuals on the ground seem to vanish; unfortunately, the total number of captured harvest mice was very low $(n=14)$ in their survey and results were not significant.

In order to improve harvest mouse detectability for biological conservation surveys and species management plans, the present study proposes to test ground versus aerial live-trapping efficiency in summer. The trapping design used paired ground and aerial traps over a 2-year survey in a reedbed. It is assumed that the harvest mouse is easier to catch above ground in summer, as individuals preferentially move in the upper strata of the herbaceous vegetation where some key resources are available: food resources with insects and seeds, by avoiding competition as well with terrestrial small mammals (Ylönen 1990), mating resources for females with thin and long leaves essential for breeding nest building and sexually active males as a result of locally available females in estrus. Moreover, harvest mice may appreciate this thick upper stratum which allows them to hide more easily from terrestrial carnivores and birds of prey (Trout 1978, Jędrzejewska and Jędrzejewski 1990, Jędrzejewski et al. 1993, Darinot 2016). Nevertheless, it is possible that other habitat features may influence the harvest mouse catchability in summer. Therefore, it is hypothesized that the density of vegetation cover enhances aerial trapping and that the thickness of leaf litter on the ground has the same effect, by making ground movement more difficult, even it is safer as protection against aerial predators.

\section{Materials and methods}

\section{Location and trapping design}

The study was conducted during 2013 and 2014, in the Réserve Naturelle du Marais de Lavours, East France (235 m above sea level, Lat $45.809227^{\circ}$ Lon $5.751525^{\circ}$ ), which is a 2000-ha wetland situated in the Rhône river floodplain. The survey station was displayed in a large (30 ha) and tall $(>2.50 \mathrm{~m}$ ) reedbed composed of common reed (Phragmites australis) mixed with reed canary grass (Phalaris arundinacea) and slender tufted sedges (Carex acuta, Carex acutiformis). The whole reedbed is annually flooded in winter and the flood level rises to, on average, $80 \mathrm{~cm}$ above ground.

A grid was established in the reedbed, from June to September of 2013, with 80 pairs of traps ( 80 aerial and 80 ground traps) within a $160 \times 15$-m study area $\left(2400 \mathrm{~m}^{2}\right)$. The arrangement of traps arose from a trade-off between, on the one hand, a regular and sufficient spacing between traps which should allow to catch every individual in its home range and, on the other hand, the difficulty for the researcher to move through the dense reedbed, which instead tends to group the traps. According to Tanaka (1966), spacing between traps should be equal to a quarter of the smallest home range diameter for the species. Thus, for the harvest mouse, a 350- $\mathrm{m}^{2}$ home range (Trout 1978) leads to up to $5 \mathrm{~m}$ spacing between traps. Moreover, the grid area was tuned to the largest known home range area, which is $1950 \pm 850 \mathrm{~m}^{2}$ (Darinot, unpublished personal communication), and a $2400-\mathrm{m}^{2}$ trapping grid was chosen. Finally, the grid was composed of 16 trap lines $10 \mathrm{~m}$ spaced, with five pairs of traps $3 \mathrm{~m}$ spaced within each line. The assembly formed a route that the researcher was able to travel in $2 \mathrm{~h}$, if the vegetation along the lines was regularly pruned. The same design was used in 2014, but a flood arose from 24 July to the end of August and all the 80 ground traps were removed, but 80 aerial traps stayed.

Aerial traps, i.e. placed above ground, were screwed to $60 \mathrm{~cm}$ plastic stakes, a type typically used in fencing to protect maize fields from wild boar. Traps were a model designed by the Institut National pour la Recherche Agronomique, INRA (Aubry 1950), which is commonly used in France for small mammal surveys. An INRA trap is composed of a $160 \times 50 \times 50-\mathrm{mm}$ aluminum tunnel coupled with a $150 \times 70 \times 70-\mathrm{mm}$ wood rest box (Figure 1). Sensitivity is very good as it was triggered by several light harvest mice weighing between 3.2 and $3.8 \mathrm{~g}$. Traps were baited with mixed seeds for birds (sunflower, wheat, millet) and were checked twice per $24 \mathrm{~h}$ at 7 A.M. and 6 P.M., except in July when traps were deliberately closed in the daytime because of a heat wave that could have killed mice in the boxes.

\section{Record of litter and vegetation}

As vegetation cover and leaf litter may influence the habitat suitability for harvest mice and their 


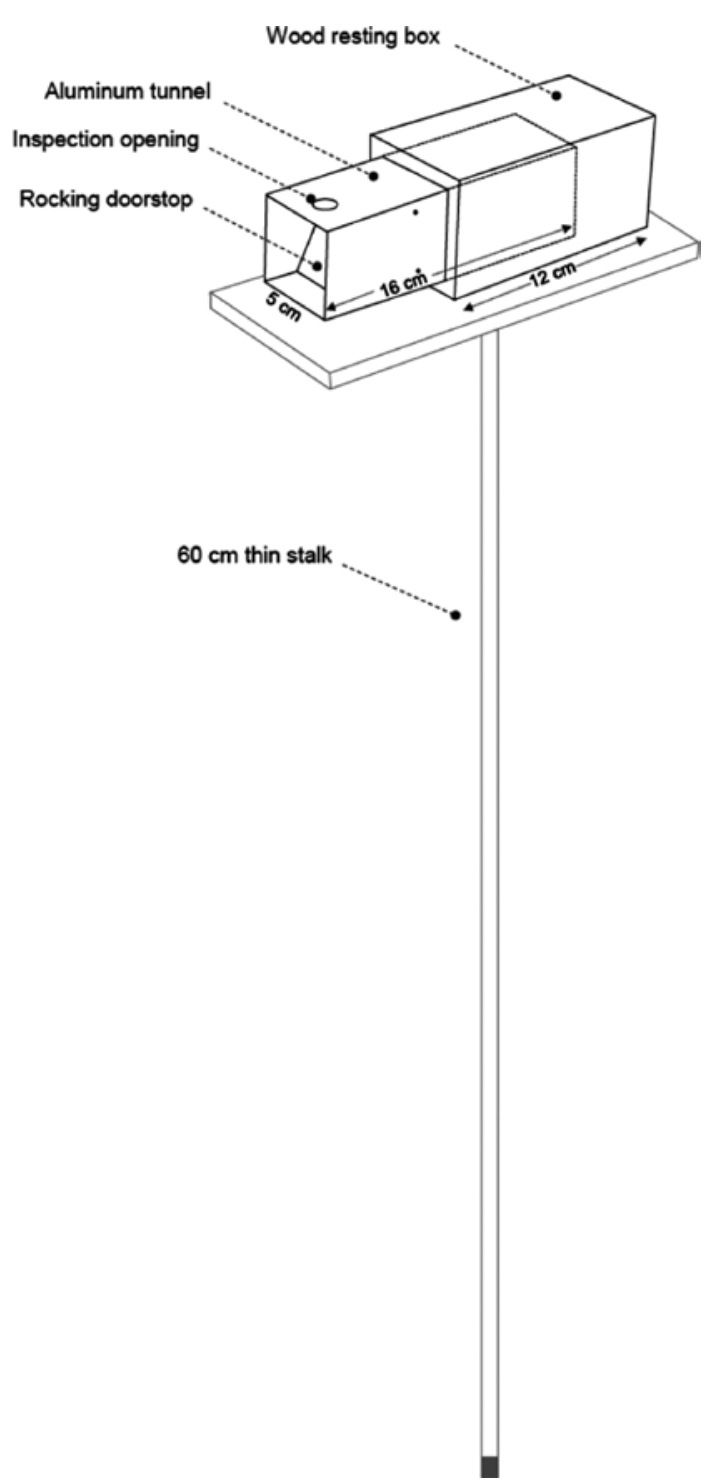

Figure 1: Scheme of an INRA trap and its installation on a stalk.

movements, measurements were made at each of the 80 trapping points. A $4-\mathrm{m}^{2}(2 \mathrm{~m} \times 2 \mathrm{~m})$ quadrat was placed against each station, to the east, within which two main types of vegetation cover were recorded: (1) the cumulated cover of reed (Phragmites australis) and reed canary grass (Phalaris arundinacea) and (2) the cumulative cover of slender sedges (Carex acuta, Carex acutiformis). Additionally, the leaf litter cover was recorded for each trapping point. For vegetation and litter cover, the cover-abundance index defined by Braun-Blanquet was used as follows: 5 , covering $>75 \%$ of the quadrat area; 4 , covering $50-75 \%$; 3 , covering $25-50 \% ; 2$, covering $>5 \% ; 1$, small cover value, $<5 \%$ (Stohlgren 2007).

\section{Data analysis}

As juveniles remain linked to their nest for a few days after weaning, they have a lower catchability likelihood than adults, so they were excluded from calculations. Although traps were checked twice per $24 \mathrm{~h}$, only morning captures were used for analysis because the number of evening captures was much lower compared to morning ones and thereby increased the dataset heterogeneity. For each species, the trapping success rate is calculated according to Nelson and Clark (1973) with the catch per unit effort (CE): CE is defined as the number of captures for one target species divided by the number of trap-nights, with an adjustment if traps were closed with capture of species other than target species. The equation is $\mathrm{CE}=\mathrm{A} \times 100 /(\mathrm{TU}-\mathrm{S} / 2)$, where $\mathrm{CE}=$ catch/effort (expressed in percentage trapping success or animals caught per 100 trapping units), $A=$ number of captured animals of the target species, $\mathrm{TU}=$ number of trapping units and $\mathrm{S}=$ total traps closed by other species.

\section{Statistical analysis}

A generalized linear mixed model was used to explain the probability of capture of harvest mouse in a trap as a function of trap position and time. Daily trap checks were expressed as a binomial distribution (presence or absence of an individual in the trap), in which the probability of capture was modeled through a logit link as a linear combination of trap position, vegetation cover and litter. An interaction term was added between vegetation cover and position to test the hypothesis that captures are more frequent in higher traps when vegetation is dense. The effects of all variables to change across survey years were further allowed through an interaction term. Non-linear variations in capture probability within seasons were accounted for by adding trapping date as a four-parameter spline, which allowed differentiation between lower and upper traps (Wood 2006). The fixed-effect part of the model was therefore: $\operatorname{logit}\left(\mathrm{p}_{\text {capture }}\right)=$ intercept + year + [position + vegetation cover + litter $+($ position $\times$ vegetation cover $)] \times$ year $+s($ days $\times$ position). Traps and trapping line were eventually added as nested random effects to account for repeated measurements within the sampling design (Zuur et al. 2009).

\section{Results}

In total, 1077 captures of small mammals were recorded during 2 years (2013 and 2014) and 10,720 trap-nights. This 
Table 1: Total captures in aerial and ground traps (noted $n: n$, respectively) and catch per unit effort (given in brackets), expressed in animals caught per 100 nights.

\begin{tabular}{|c|c|c|c|c|}
\hline \multirow[t]{2}{*}{ Species } & 2013 & \multicolumn{2}{|r|}{2014} & \multirow{2}{*}{$\begin{array}{r}\text { Total } \\
10,720 \\
\text { trap-nights }\end{array}$} \\
\hline & $\begin{array}{r}160 \text { traps, } \\
49 \text { nights } \\
7840 \text { trap-nights }\end{array}$ & $\begin{array}{r}160 \text { traps, } \\
8 \text { nights } \\
1280 \text { trap-nights }\end{array}$ & $\begin{array}{r}\text { Flooding } \\
80 \text { traps, } 19 \text { nights } \\
1520 \text { trap-nights }\end{array}$ & \\
\hline Harvest mouse & $342: 189$ & $70: 24$ & 290:0 & $702: 213$ \\
\hline Micromys minutus & $(8.7: 4.9)$ & $(5.5: 1.9)$ & $(19: 0)$ & $(11.6: 4.8)$ \\
\hline Wood mouse & $14: 50$ & $0: 17$ & $0: 0$ & $14: 67$ \\
\hline Apodemus sylvaticus & $(0.4: 1.3)$ & $(0: 1.4)$ & & $(0.2: 3.1)$ \\
\hline Field vole & $1: 47$ & $0: 8$ & $0: 0$ & $1: 55$ \\
\hline Microtus agrestis & $(0: 1.2)$ & $(0: 0.6)$ & & $(0: 1.6)$ \\
\hline European water shrew & $0: 15$ & $0: 0$ & $0: 0$ & $0: 15$ \\
\hline Neomys fodiens & $(0: 0.4)$ & & & $(0: 0.3)$ \\
\hline White-toothed shrew & $0: 9$ & $0: 1$ & $0: 0$ & $0: 10$ \\
\hline Crocidura russula & $(0: 0.2)$ & $(0: 0.7)$ & & $(0: 0.2)$ \\
\hline Total & $357: 310$ & $70: 50$ & 290:0 & $717: 360$ \\
\hline & $(9.1: 7.9)$ & $(5.5: 3.9)$ & $(19: 0)$ & $(11.8: 7.9)$ \\
\hline
\end{tabular}

corresponds to a global trapping success equal to $10 \%$. Among the five species of small mammals that were captured (Table 1), the harvest mouse represented $84.96 \%$ of total captures and $15.26 \%$ of trapping success. It was the only species which was more trapped above ground $(n=702)$ than on the ground $(n=213)$ and the only one which continued to be trapped in 2014 during summer flooding.

Capture probability of harvest mice did not differ between years (year effect, $F_{1, x x}=1.68, p=0.19$ ) and increased near-linearly from April to July (day spline, estimated degree of freedom $=1.57, \mathrm{~F}=16.37, \mathrm{p}<0.001$ and $1.81, \mathrm{~F}=50.71, \mathrm{p}<0.001$ for lower and upper traps, respectively) (Figure 2). Capture probability was significantly higher in upper than in lower traps in both years, but the effect of trap position was even stronger in 2014 (Figure 3). Litter had a slightly positive effect on capture probability of harvest mice in 2014 (litter $\times$ year interaction term, $\mathrm{F}_{1, \mathrm{Xx}}=5.005, \mathrm{p}<0.02$ ) (Figure 4A), but harvest mice were less likely captured under dense vegetation cover, irrespective of year and position (position $\times$ cover $\times$ year effect, $\mathrm{F}_{1, \mathrm{xx}}=3.11, \mathrm{p}=0.08$ ) (Figure 4B).

\section{Discussion and conclusion}

This study provides robust results showing much higher efficiency of aerial over ground live-trapping for harvest mouse. This supports the hypothesis that, in summer, harvest mice are easier to catch above ground than on the ground in reedbed. However, this species was still captured on the ground, as has been reported in some studies with only

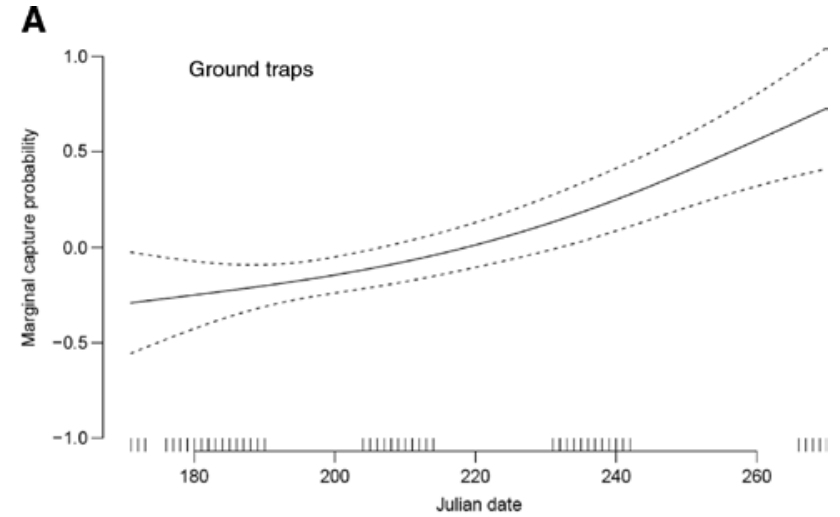

B

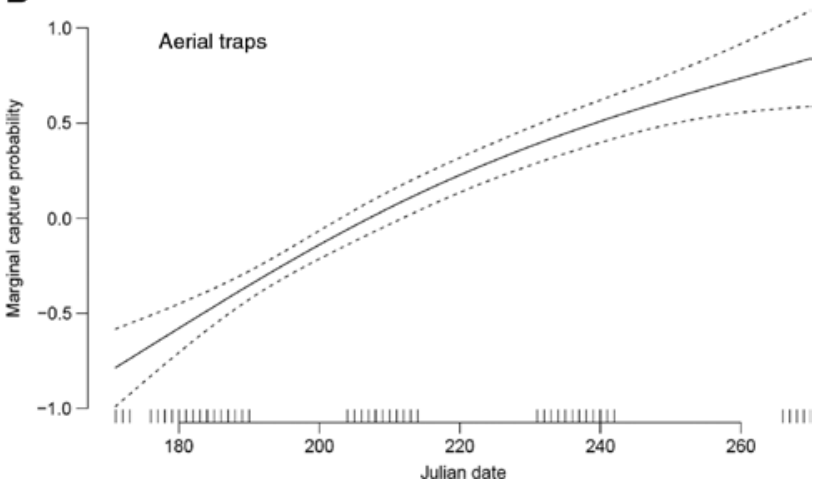

Figure 2: Effect of trapping date on capture probability of harvest mouse for (A) ground traps and (B) aerial traps, as estimated by a generalized additive mixed model adjusted for years, vegetation cover, litter and sampling design.

Plain and dashed curves represent marginal predictions of date effect and its $95 \%$ confidence interval as modeled by a spline smoother. Tick marks on the $x$ axis display the location of data points. 


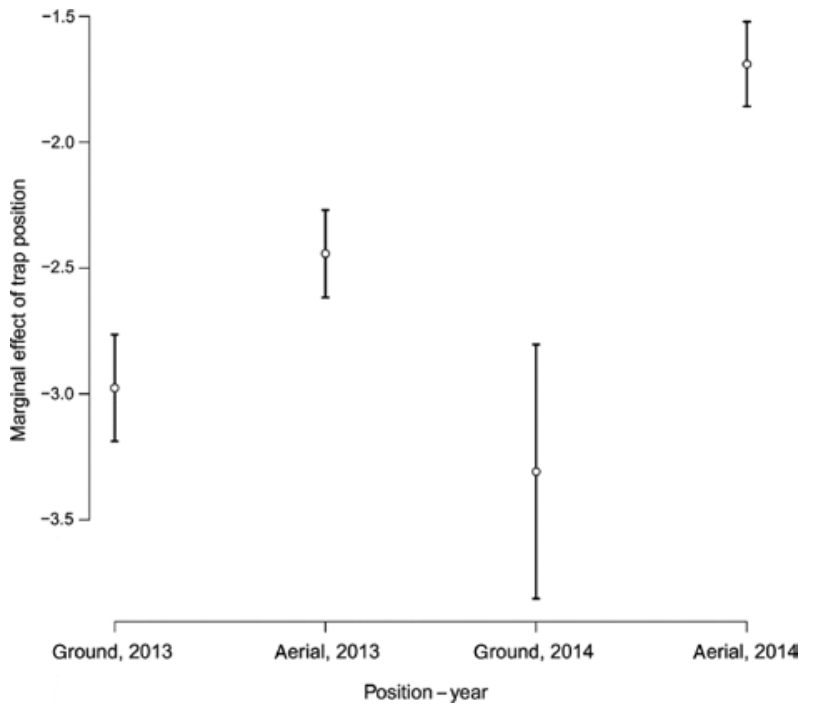

Figure 3: Marginal effects of trap position, per year, estimated by a generalized additive mixed model adjusted for litter, vegetation cover, trapping date and sampling design.

ground trapping (Jensen and Hansen 2003, Scott et al. 2008, Vogel and Gander 2015). If the flooded period is excluded, ground traps provided $34 \%$ of total captures of harvest mouse, which is consistent with the $24 \%$ found by Perrow and Jowitt (1995) in a range of wetland vegetation types. This means that mice occupied the entire volume of the vegetation, from the ground where they made some incursions to the upper strata where they were almost the sole small mammal to move, accompanied by some scarce wood mice and field voles. As a result, for studies on population dynamics of harvest mouse where there is a need to catch most of individuals, mixed ground and aerial live-trapping is recommended; for specific purposes, the use of aerial without ground traps may be appropriate as this avoids almost all other species and then prevents trap saturation. However, in some types of habitat, even aerial traps may be saturated by other muroid rodents like the wood mouse (Apodemus sylvaticus) or the yellow-necked mouse (Apodemus flavicollis), to the detriment of the harvest mouse.

Second, these results show that the harvest mouse is the only species to be captured during flooding in aerial traps and the large number of individuals strongly suggests that this species resists flooding, as previously reported by Kettel et al. (2016). Thus, aerial trapping allows harvest mouse surveys even during flood events, which may offer very interesting results for the understanding of this species behavior.

Third, the findings do not support the hypothesis that the density of vegetation cover is positively correlated with the catchability of harvest mouse in aerial traps, in reed, reed canary grass and slender sedge habitats. In other words, the detection probability of occurrence seems not to be influenced by the density of reedbed. However, additional studies should specify if it is the detection probability itself or the density of individuals which varies with vegetation cover. Furthermore, the thickness of leaf litter only slightly, but significantly, enhanced aerial trapping. This dry litter can reach a thickness that exceeds $10 \mathrm{~cm}$ in some parts of the reedbed, but does not really stand on the ground, which probably allows mice to move under the litter where traps were deployed. From a practical point of view, ground traps should be set up even if there is leaf litter and additional surveys should specify if the harvest mouse detectability is better above or below litter.

An additional finding of this study is that the harvest mouse accounted for the large majority of trapping events and that it represented by far the majority species of the small mammal community. This tends to confirm that reedbeds are very suitable habitats for this species, as already mentioned by some other authors (Haberl and Kryštufek 2003, Perrow and Jowitt 2003, Surmacki
A

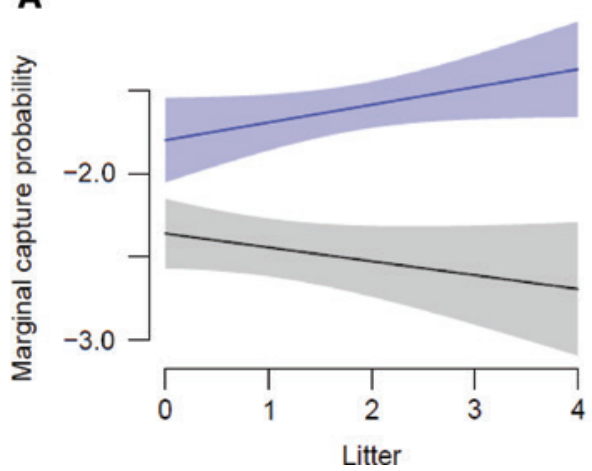

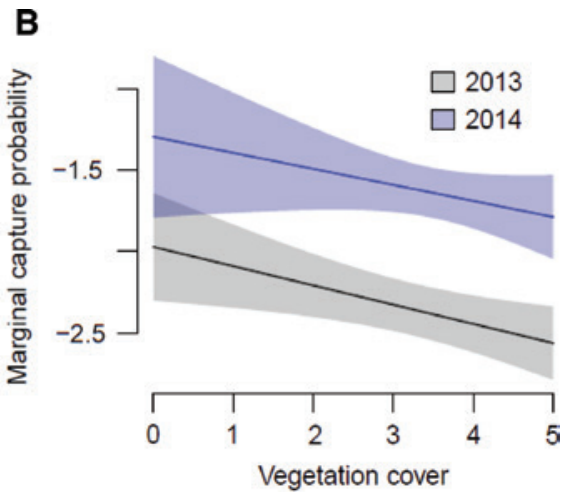

Figure 4: Colored areas represent $95 \%$ confidence interval of the marginal predictions. Marginal effect of (A) litter cover and (B) vegetation cover (both shown in cover-abundance indices) on marginal capture probability per year, adjusted for trap position, trapping date and sampling design in a generalized additive mixed model. 
et al. 2005, Amori et al. 2008, Kettel et al. 2016). However, old reedbeds with thick stalks seem unsuitable for harvest mice (Piechocki 1958) because they can barely grip those stalks, having more difficulty in moving across vegetation (Karantanis et al. 2018). The harvest mouse prefers mixed reeds with sedges and grasses (Surmacki et al. 2005, Blant et al. 2012) as found in this survey.

It is now recognized that aerial trapping is absolutely required for harvest mouse studies, whatever the season be. For species management plans, one of the main advantages of its efficiency is that it allows reduced time spent in monitoring and eventually maximizing the number of trapping stations, even if the harvest mouse is not the only small mammal species efficient at climbing. For further ecological surveys, it would be interesting to focus on the three-dimensional space occupancy of the harvest mouse which is a rare behavior among rodents, according to habitat parameters, individual sex and interactions with other small mammal species.

Acknowledgments: This work was supported by the French Environment Ministry and the Departmental Council of Ain. The author wishes to thank the students who helped him in the field: Pauline Jacob, Samuel Lyonnet and Guillaume Viallard, as well as Françoise Poitevin (CEFE-CNRS EPHE Montpellier) for reviewing an earlier version of the manuscript and Jean-Yves Barnagaud (CEFE-CNRS EPHE Montpellier) for his help in data analysis of the submitted version. Phil Withers kindly improved the English language.

\section{References}

Amori, G., L. Contoli and A. Nappi. 2008. Fauna d'Italia. Mammalia II. Ed. Calderini. pp. 736.

Aplin, K., D. Lunde, N. Batsaikhan, B. Kryštufek, H. Meinig and H. Henttonen. 2008. Micromys minutus. IUCN Red List of Threatened Species http://www.iucnredlist.orgn (Downloaded on 09.06.2019).

Aubry, J. 1950. Deux pièges pour la capture des petits rongeurs vivants. Mammalia 14: 174-177.

Blant, M., P. Marchesi, M. Descombes and S. Capt. 2012. Nouvelles données sur la répartition de la souris des moissons (Micromys minutus Pallas, 1771) en Suisse occidentale et implications pour la gestion de son habitat. Rev. Suisse Zool. 119: 485-500.

Butet, A. 1994. Nutritional conditions and annual fluctuations in Apodemus sylvaticus populations. Russ. J. Ecol. 25: 111-119.

Butet, A. and G. Paillat. 1997. Insectivores et rongeurs de France: le mulot sylvestre Apodemus sylvaticus (Linné, 1758). Arvicola 9: 7-23.

Darinot, F. 2016. The harvest mouse (Micromys minutus Pallas, 1771) as prey: a literature review. Folia Zool. 65: 117-134.
Flowerdew, J.R., R.F. Shore, S.M.C. Poulton and T.H. Sparks. 2004. Live trapping to monitor small mammals in Britain. Mammal Rev. 34: 31-50.

Gu, W. and R.K. Swihart. 2004. Absent or undetected? Effects of non-detection of species occurrence on wildlife-habitat models. Biol. Conserv. 116: 195-203.

Haberl, W. and B. Kryštufek. 2003. Spatial distribution and population density of the harvest mouse Micromys minutus in a habitat mosaic at Lake Neusiedl, Austria. Mammalia 67: 355-365.

Harris, S., P. Morris, S. Wray and D. Yalden. 1995. A review of British mammals: population estimates and conservation status of British mammals other than cetaceans. The Joint Nature Conservation Committee, Peterborough, UK.

Jędrzejewska, B. and W. Jędrzejewski. 1990. Antipredatory behaviour of bank voles and prey choice of weasels - enclosure experiments. Ann. Zool. Fennici 27: 321-328.

Jędrzejewski, W., L. Rychlik and B. Jędrzejewska. 1993. Responses of bank voles to odours of seven species of predators: experimental data and their relevance to natural predator-vole relationships. Oikos 68: 251-257.

Jensen, T.S. and T.S. Hansen. 2003. Biodiversity and habitat distribution of small mammals in Danish arable land. Flora og Fauna 109: 9-21.

Karantanis, N.E., L. Rychlik, A. Herrel and D. Youlatos. 2018. Vertical locomotion in Micromys minutus (Rodentia: Muridae): insights into the evolution of Eutherian climbing. J. Mamm. Evol. 25: 277-289.

Kettel, E.F., M.F. Perrow and T. Reader. 2016. Live-trapping in the stalk zone of tall grasses as an effective way of monitoring harvest mice (Micromys minutus). Eur. J. Wildlife Res. 62: 241-245.

MacKenzie, D.I. and J.A. Royle. 2005. Designing occupancy studies: general advice and allocating survey effort. J. Appl. Ecol. 42: $1105-1114$.

Nelson, L. and F.W. Clark. 1973. Correction for sprung traps in catch/ effort calculations of trapping results. J. Mammal. 54: 295-298.

Nordvig, K., J. Reddersen and T.S. Jensen. 2001. Small mammal exploitation of upper vegetation strata in non-forest mixed farmland habitats. Mamm. Biol. 66: 129-134.

Perrow, M.R. and A.J.D. Jowitt. 1995. What future for the harvest mouse? British Wildlife 6: 356-365.

Perrow, M.R. and A.J.D. Jowitt. 2003. Wetlands as an important habitat for small mammals. British Wildlife 14: 171-179.

Piechocki, R. 1958. Die Zwergmaus, Micromys minutus Pallas. Neue Brehm-Bücherei, Heft 22, A. Ziemsen Verlag Wittenberg, Lutherstadt.

Riordan, P., A. Lloyd and D.W. Macdonald. 2009. Do harvest mouse nest survey results predict population size? Report to People's Trust for Endangered Species, London. pp. 10.

Rowe, F.P. and E.J. Taylor. 1964. The number of harvest mice (Micromys minutus) in corn ricks. Proc. Zool. Soc. London 142: 181-185.

Scott, D.M., C.B. Joyce and N.G. Burnside. 2008. The influence of habitat and landscape on small mammals in Estonian coastal wetlands. Est. J. Ecol. 57: 279-295.

Sleptsov, M.M. 1947. The biology of Micromys minutus ussuricus B.Ham. (In Fauna i ekologiya gryzunov 2. Materialy k poznaniyu fauny i flory SSSR, 8"). Issue 2. Moscow: MOIP. pp. 69-100 (in Russian).

Stohlgren, T.J. 2007. Measuring plant diversity: lessons from the field. Oxford University Press, New York. pp. 408. 
Surmacki, A., B. Gołdyn and P. Tryjanowski. 2005. Location and habitat characteristics of the breeding nests of the harvest mouse (Micromys minutus) in the reed-beds of an intensively used farmland. Mammalia 69: 5-9.

Tanaka, R. 1966. A possible discrepancy between the exposed and the whole population depending in range size and trap spacing in vole populations. Res. Popul. Ecol. 8: 93-101.

Trout, R.C. 1978. A review of studies on population of wild harvest mice (Micromys minutus Pallas). Mamm. Rev. 8: 143-158.

Vogel, P. and A. Gander. 2015. Live trapping design for the harvest mouse (Micromys minutus) in its summer habitat. Rev. Suisse Zool. 122: 143-148.

Warner, L.J. and G.T. Batt. 1976. Some simple methods for recording wild harvest mouse (Micromys minutus) distribution and activity. J. Zool. 179: 226-229.
Watkins, A.F., J.L. McWhirter and C.M. King. 2010. Variable detectability in long-term population surveys of small mammals. Eur. J. Wildlife Res. 56: 261-274.

Wilson, D.E., T.E. Lacher and R.A. Mittermeier. 2016. Handbook of the mammals of the world - volume 7 rodents II. Lynx Edicions, Barcelona. pp. 1008.

Wood, S.N. 2006. Generalized additive models. An introduction with R. Chapman \& Hall, CRC Press, London \& New York. pp. 416.

Ylönen, H. 1990. Spatial avoidance between the bank vole Clethrionomys glareolus and the harvest mouse Micromys minutus - an experimental study. Ann. Zool. Fennici 27: 313-320.

Zuur, A., E.N. leno, N. Walker, A.A. Saveliev and G.M. Smith 2009. Mixed effects models and extensions in ecology with $R$. Springer Ed., New York. pp. 529. 